\title{
PERBEDAAN PERILAKU PROSOSIAL BERDASARKAN ORIENTASI PERAN JENIS
}

\author{
Danny Oscar P. \\ Vivi Gusrini R.Pohan \\ Universitas Sumatra Utara
}

\begin{abstract}
Prosocial behaviour emerge based on some factors like situational factor and personal factor, including gender issues. Many researchers who have concern on prosocial behavior in different gender; among others is a study of meta-analyses of college student and senior high school conducted by Eagly and Crowley (1992), showing result that man are more helping than woman consistently. This research is conducted to study funther the role of gender orientation on the emergence of prosocial behavior. This research entangle 200 students in University of North Sumatra which consists of 100 man and 100 wornan selected by using technique of incidental sampling. Scale of prosocial tendency relying on the forms of prosocial behavior by Amato (1990) and scale of role of gender orientation pursuae to Bem's theory(1974) is used to measure the prosocial behavior. Reliability of prosocial tendency scale is equal to 0,962 and rofe of gender orientation scale is equal to 0,865. Data analyze by one-way ANOVA.

Result of data analysis shows that there is difference role of gender orientation among groups of masculine, femininee, androgyny and unclassified in prosocial tendency; with $F$ value $=$ 3,279 , probability of $p=0,022$. And peculiarly visible difference is between group of androgyny and unclassified group, posed at with probability value equal to 0,018 . Result oft-test indicate that there is difference in prosocial tendency between the subject group of man and woman, with Fvalue $=1,888$, probability of pequalto 0,014 .
\end{abstract}

Keywords: pro social behavior, role of gender orientation, masculine, feminine, androgyny

\section{Pengantar}

Di antara banyak kisah yang dipublikasikan lewat media-media, yang menarik untuk diperhatikan adalah Kisah mengenai altruisme dan perilaku sosial positif di antara kita. Salah satunya adalah peristiwa pemboman of dua tempat hiburan di Bali, Pulau Dewata, yang menjadi tempat wisata kebanggaan Indonesia karena sudah terkenal sampai ke seluruh dunia. Peristiwa pemboman di Bali pada tanggal 12 Oktober 2002 yang lalu menjadi sebuah tragedi yang kembali mengguncang dunia semenjak tragedi Worid Trade Centre yang menelan korban hingga ribuan jiwa.

Media massa juga memberitakan adanya orang-orang yang datang dan menyediakan diri sebagai relawan untuk menolong korban dari peristiwa tersebut. Para relawan itu tidak hanya datang dari daerah-daerah di sekitar Bali sendíri, tetapi juga berasal dari beberapa negara lain. Ada beberapa dari antara mereka yang begitu menyaksikan peristiwa tragis itu di televisi langsung memesan tiket dan mengurus dokumen perjalanan lalu berangkat ke Bali untuk menjadi relawan. Di sana mereka membantu untuk mengurusi mayat korban, membantu merawat korban yang terluka, membantu masyarakat yang mencari keluarga mereka, dan beberapa hal yang lain yang juga merupakan pekerjaan mereka sehari-hari (Kompas, 1 November 2002).

Sebuah peristiwa yang masih segar di dalam ingatan bangsa Indonesia adalah bencana terbesar dalam abad îni yang mengejutkan seluruh dunia. Bencana alam 
gempa bumi dan dilkuti oleh tsunami yang terjadi di Aceh dan Sumatra Utara yang telah mengakibatkan begitu banyaknya korban materiai dan korban jiwa, yang bahkan melebihi catatan korban jiwa yang pemah dicatat oleh sejarah modern. Lebih dari 220.000 jiwa tewas dalam bencana itu, dan menyebabkan 440.000 jwa lainnya harus kehilangan tempat tinggal setelah gelombang besar. Gempa besar yang memiilki kekuatan 8,7 skala Richter telah mengguncang wilayah Aceh, Sumatera Utara, Riau, Sumatera Barat, dan bahkan mencapai wilayah Thailand (Kompas, 2 Februari 2005).

Tidak hanya sampai di situ saja, gempa tu bukan satu-satunya kejadian yang mengejutkan, pada Minggu pagi, 26 Desember 2004. Seteiah beberapa saat sebuah maut melanda wilayah yang bahkan jauh lebih luas dari pada cakupan gempa pertama tadi. Tsunami tel ah meianda daerahdaerah yang lebih luas lagi, meliputi negara Indonesia, Thailand, Malaysia, India, Srilanka, Burma, Vietnam. Dengan segera dunia memberikan respon. Bantuan yang diarahkan ke daerah bencana sifatnya global, tidak hanya dari dalam negeri saja, tetapi bantuan yang datangnya dari seluruh penjuru dunia ditujukan untuk bencana tersebut (Kompas, 03 Februari 2005).

Ketika kecurigaan, prasangka, dan egosentrisme melanda dan korban berjatuhan di mana-mana, ada saja orang yang menyediakan diri untuk menolong orang lain tanpa mementingkan diri sendiri (sebuah konsep yang dikenal sebagai altruisme). Topik mengenai hal ini menarik perhatian beberapa peneliti di bidang sosial (Myers, 2001).

Lalu yang selanjutnya diperhatikan adalah alasan yang melatarbelakangi perilaku semacam itu. Hal ini perlu diselidiki lebih jauh apa yang mendorong mereka berbuat tanpa pamrih tersebut. Padahal orang-orang tersebut tidak mendapatkan bayaran, tidak memilikj kepentingan untuk mengharumkan nama pribadi, tidak bermaksud mendapat popularitas, dan berbagai kepentingan lain yang tidak tulus.

Banyak penelitian yang sudah dilakukan untuk melihat perilaku menolong pada jenis kelamin yang berbeda. Sebagian besar penelitian ini menggunakan metode quasi eksperimen atau eksperimen lapangan untuk dapat melihat secara langsung perilaku yang ditampilkan oleh subjek penelitian di dalam setting yang alami. Sebuah survei nasional juga diakukan di Amerika Serikat terhadap siswa-siswa perguruan tinggi dan sekolah menengah atas, secara konsisten menunjukkan bahwa wanita menunjukkan perhatian yang lebih besar untuk memberikan pertolongan dibandingkan dengan prla (Basow, 1992).

Meskipun begitu, ketika pengukuran dilakukan terhadap perilaku menoiong yang aktual, hasilnya menunjukkan tidak terdapat perbedaan yang signifikan antara pria dan wanita (Maccoby \& Jacklin; Pillavin \& Unger Basow, 1992). Sekalipun ditemukan perbedaan, maka kecenderungan yang lebih besar akan mengarah kepada pria, bukan wanita (Brigham, 1986; Saks \& Krupat, 1988; \& Basow, 1992). Hal ini didukung oleh hasil yang diperoleh Eagly dan Crowley (Basow, 1992; Taylor dkk 2000) melalui sebuah review meta-analisis yang dilakukan terhadap 172 penelitian mengenai perilaku prososial.

Simpulan yang diperoleh dari review meta-analisis menunjukkan bahwa pria iebih me no fong daripada wanita, di mana pria lebih cenderung untuk menawarkan pertolongan daripada wanita; walaupun wantia dinilai lebih menolong daripada pria dan kelihatannya lebih peduli untuk memberikan pertolongan, riset behavioral menyatakan bahwa pria lebih penolong daripada wanita, paling tidak dalam situasi publik yang mielibatkan orang yang tidak dikenal (Basow, 1992).

Menurut Myers (2001), pada dasarnya, perilaku prososiai yang ditampilkan bergantung pada beberapa faktor; seperti faktor situasional (jumlah bystander, apakah orang lain juga memberikan pertolongan pada saat itu, termasuk tekanan waktu); dan faktor personal (perasaan, motivasi, mood, traittrait kepribadian, gender, juga termasuk keyakinan seseorang). Dalam hal ini, yang 
menjadi salah satu trait kepribadian yang mempengaruhi perilaku prososial adalah empati, yaitu sebuah respon emosional yang berhubungan dengan perasaan-perasaan orang lain. Bagaimana memberikan respon ketika seseorang mengalami kesuiltan, turut merasakan kesulitan orang itu; dan ketika seseorang sedang sedih, turut merasakan kesedihan orang iu (Feldman, 1995).

Feidman (1995) kemudian menyebutkan bahwa ketika seseorang memilikl empati yang tinggi, maka kecenderungan untuk memberikan pertolongan juga tinggi. Jika dipenatikan lebih lanjut lagi, Basow (1992) menyebutkan bahwa empati lebih merupakan sebagai salah sału ciri pada aspek feminitas. Empati yang diharapkan muncul dari seseorang memungkinkan seseorang untuk dapat lebih peka terhadap perasaan orang lain.

Dapat dikatakan bahwa walaupun perbedaan jenis kelamin mejatarbelakangi sebagian besar penelitian-penelitian di atas, namun bisa jadi yang menjadi latar belakang perilaku prososial lebih pada variabel peran jenis dari penolong yang terlibat, apakah dia masculine, feminine, atau androgyny. Dengan begitu. penulis bermaksud untuk membahas lebih jauh mengenai perbedaan peran jenis ini daiam hal perilaku prososial.

\section{DasarTeori}

Perilaku prososial melipuli antara lain tindakan-tindakan baik yang direncanakan secara formai dan informal atau yang bersifat spontan (Amato, 1990); dan juga melibatkan pemberian bantuan baik secara langsung atau tidak langsung yang bertujuan untuk menolong orang lain tanpa melihat alasan untuk melakukannya (Smithson okk dalam Saks \& Krupat, 1988).

Berdasarkan frekuensi pemberian bantuan. Amato (1990) membagi bentuk perilaku prososial yang diberikan setiap harinya ke dalam 3 (tiga) bentuk mendasar yaitu formal planned helping, informal planned helping, dan spontaneous or unplanned helping. Menolong yang direncanakan (planned helping) berarti bahwa orang akan berpikir lebih jauh terhadap pertolongan yang dia berikan kepada orang lain; dan menoiong spontan (spontaneous helping) adalah bantuan yang diberikan seketika. Menolong secara formal (formal helping) adalah bentuk pertolongan yang diberikan kepada sebuah organisasi formal; sementara menolong secara informa! (informal helping) berarti pertoiongan yang diberikan kepada teman, keluarga, termasuk kepada orang yang tidak dikenal (Amato, 1990).

Secara umum, perilaku prososial dipengaruhi oleh dua faktor, yaitu faktor siltuasionai dan faktor personal. Faktor situasional meliputi karakteristik dari orang yang membutuhkan pertolongan, jumlah serta kehadiran dari bystanderserta tekanan waktu. Faktor personal yang mempengaruhi perilaku prososial antara lain faktor adalah emosi, perasaan, empati, trait-trait kepribadian, dan mood, selain itu juga norma-norma (Myers, 1996).

Peran jenis adalah pola perilaku yang dianggap sesuai untuk masing-masing jenis kelamin yang didasarkan pada harapan masyarakat. Menurut Myers (1996), peran jenis merupakan suatu set perilaku yang diharapkan (berupa norma) untuk pria dan wanita. Hal ini meliputi sikap dan juga pola perilaku yang dianggap cocok untuk pria dan wanita, dikaitkan dengan ciri-ciri feminine dan masculine sesuai dengan yang diharapkan dalam masyarakat.

Bern (Basow, 1992) menyatakan bahwa terdapat dua modei orientasi peran jenis di daiam menjeiaskan mengenai maskulinitas dan femininitas dalam kaitannya dengan pria dan wanita, yaitu model tradisional dan model nontradisional (Nauly, 2003). Model tradisional memandang maskulinitas dan femininitas sebagai sebuah dikotoml. Model tradisional menyebutkan bahwa maskuinitas dan femininitas merupakan titik-titik yang berlawanan pada sebuah kontinum yang bipoiar. Pengukuran yang ditujukan untuk melihat maskulinitas dan femininitas menyebabkan derajat yang tinggi dari maskulinitas yang menunjukkan derajat yang rendah dari femininitas; begitu juga sebaliknya, derajat yang tinggi darl femininitas menunjukkan derajat yang 
rendah dari maskulinitas.

Pandangan nontradisional menyatakan bahwa maskulinitas dan feminitas lebih sesuai dikonseptualisasikan secara terpisah, dl mana masing-masing merupakan dimensi yang independen.

Model yang kedua ini memandang feminitas dan maskulinitas bukan merupakan sebuah dikotomi. Hal ini menyebabkan kemungkinan untuk adanya pengelompokan yang lain, yaitu androgyny, yaitu pria atau wanita yang dapat memiliki ciri-ciri maskulinitas sekaligus ciri-ciri feminitas. Pengelompokkan peran jenis terdiri dari 4 (empat) kelompok, yaitu :

a. Masculine (high $M+$ low $F$ )

b. Feminine (high $\mathrm{F}+$ low $\mathrm{M}$ )

c. Androgyny(highM+highF)

d. Undifferentiated, atau tidak terklasifikasikan (low $M+$ low $F$ )

Banyak penelitian yang dilakukan berusaha untuk menemukan perbedaan of dalam perilaku menolong yang didasarkan atas perbedaan gender, antara lain yaitu penelitian yang dilakukan oleh Alice Eagly dan Maureen Crowley pada tahun 1986 (Myers, 1996). Penelitian ini dilakukan terhadap 172 studl yang telah melakukan perbandlngan antara perilaku prososial antara 50.000 subjek pria dan wanita. Mereka memperoleh berbagai hasil yang dapot dijadikan sebagai acuan berpikir. Setelah melakukan penelitian terhadap studi-studi tersebut, Eagly dan Crwoley (Basow, 1992) menemukan bahwa perbedaan antara pria dan wanita mungkin sedikit, tetapi konsisten. Pria dinilai lebih menolong daripada wanita, dan terryala wanita lebih cenderung untuk menerima pertolongan. Pria tidak lebih merıolong daripada wanita ketika situasi yang dihadapi menuntut empati atau dukungan soslal yang sifatnya kurang aktif (Iess-active social support) (Basow, 1992). Tice dan Baumeister (1985) menghipotesiskan bahwa trait-trait kepribadian yang berhubungan dengan faktor-faktor tersebut dapat mempengaruhi intervensi. Keduanya juga menyebutkan bahwa faktor-faktor ini berhubungan dengan konsep budaya Amerika mengenai identitas gender, Kemudian melakukan penelitian dengan memberikan Bem Sex Role Inventory kepada subjek penelitian. Mereka mempredlkslkan bahwa faktor-faktor kepribadian atau gender ini akan mempengaruhi perilaku menolong. Mereka menghipotesiskan bahwa maskulinitas dapat menjadi faktor penghambat tetapi juga sekaligus menjadi faktor pemicu dari munculnya perilaku menolong; femlninitas merupakan pemicu dan androgyny juga merupakan pernicu.

\section{Hipotesis}

Ada perbedaan perilaku prososial ditinjau dari orlentasi peran jenis masculine, feminine, dan androgyny.

\section{Metode}

Populasi dalam ini penelitian adalah mahasiswa Universitas Sumatera Utara, tanpa harus menspesifikkan terhadap lingkungan fakultas tertentu. Teknik sampling yang digunakan adalah dengan incidental sampling, dengan jumlah sampel dalam penelitian ini adalah 200 orang; sedangkan untuk uj coba alat ukur (try out) dilakukan terlebih dahulu terhadap 41 orang responden untuk kedua skala perilaku prososial dan ska la orientasi peran jenis.

Penelitian ini akan menggunakan 2 (dua) buah skala sebagai alat ukur. Yang pertama adalah skala yang mengukur perilaku menampilkan perilaku prososial, serta yang kedua akan menentukan peran jenis seseorang. Alat ukur yang akan digunakan untuk melihat kecenderungan dalam menampilkan perilaku prososial adalah Skala Prososial. Skala didasarkan pada 3 (tiga) komponen dari konsep perilaku prososial oleh Paul R. Amato (1990). Skala ini mengungkap mengenai kecenderungan seseorang di dalam menampilkan perilaku prososial. Model skala menggunakan 4 (empat) pilihan penskalaan model Likert dengan metode rating dan menggunakan distribusi respon terhadap pernyataanpernyataan sebagai penentuan nilal skaia, yaitu : Sangat Setuju (SS), Setuju (S), Tidak Setuju (TS), dan Sangat Tidak Setuju (STS). 
Penilaian terhadap pernyataan-pernyataan dimulai dari angka 1 sampai 4, dengan niliai 1 untuk pilihan jawaban Sangat Tidak Setuju, nilai 2 untuk pilihan jawaban Tidak Setuju, nilai 3 untuk pilihan jawaban Setuju, serta nilai 4 untuk pilihanjawaban Sangat Setuju.

Hasil tryout menunjukkan bahwa setelah uji coba dari 87 aitem skala perilaku prososial dengan jumlah subjek 41 orang $(n=$ 41) terdapat 51 aitem yang dianggap memiliki angka validitas yang mernadai untuk dapat digunakan dalam penelitian $(-0,300)$, dengan reliabilitas alpha 0 sebesar 0,962 . Koefisien determinasi aitem-aitem yang valid bergerak dari 0,303 sampai 0,775 .

Alat ukur yang kedua adalah skala orientasi peran jenis. Skala ini diadaptasi dari Skala M-F (Masculine-Feminine). Skala ini merupakan pengernbangan dari Bem Sex Role Inventory (BSRI). Skala ini terdiri dari 60 (enarn puluh) aitem. Alat ukur ini menggunakan 7 (tujuh) skala respon mulai dari skala 1 untuk tidak pernah atau hampir tidak benar (never or almost never true) sampai skala 7 (tujuh) untuk menyatakan selalu atau hampir selalu benar (always or almost always true).

Subjek akan dikelompokkan ke dalam empat orientasi peran jenis dengan mellhat skor yang diperoleh subjek dalarn masing-masing subkomponen masculine dan komponen feminine. Lalu orientasi peran jenis subjek akan ditentukan dengan: masculine, jika skor masculine tinggi dan skor feminine rendah; feminine, jika skor feminine tinggi dan skor masculine rendah; androgyny, jika skor masculine dan feminine sama-sama tinggi; dan undifferentiated, jika skor masculine dan feminine sama-sama rendah.

Hasil tryout menunjukkan bahwa setelah uj coba dari 60 aitem skala orientasi peranjenis dengan jumlah subjek 41 orang (n $=41$ ) terdapat 32 aitem yang dianggap merniliki angka validitas yang mernadai untuk dapat digunakan dalarn penelitian $(-0,300)$, dengan reliabilitas alpha 0 sebesar 0,865 . Koeffsien determinasi aitem-aitem yang valid bergerakdari 0,315 sampai 0,711 .

Pengolahan data utama dalam penelitian adalah dengan menggunakan teknik statistikAnalysis of Variance (ANOVA) dengan menggunakan SPSS for Windows versi 12.0 .

\section{Hasil}

Berdasarkan hasil yang diperoleh dalarn penelitian ini, dapat dibuat beberapa kesimpulan, yaitu:

1. Ada perbedaan yang signifikan antara kelompok orientasi peran jenis masculine, feminine, androgyny dan kelornpok yang tidak terklasiffkasikan dalarn skor perilaku prososial.

2. Kelompok orientasi peran jenis androgyny berbeda secara signifikan dengan kelompok yang tidak terklasifikasikan dalarn skor perilaku prososial.

3. Kelompok orientasi peran jenis androgyny merniliki skor perilaku prososial yang relatif lebih tinggi dibandingkan kelompok orientasi peran jenis masculine, feminine, dan yang tidak terklasifikasikan.

4. Terdapat perbedaan yang signifikan dalarn nilai rata-rata skor perilaku prososial antara kelompok subjek pria dan wanita berdasarkan hasil perhitungan t-test; kelompok subjek wanita merniliki skor perilaku prososial yang lebih tinggi dari pada kelompok pria.

\section{Pernbahasan}

Hasil utarna dalam penelitian ini menunjukkan bahwa terdapat perbedaan perilakı prososial yang signifikan antara kelornpok orientasi peran jenis masculine, feminine, androgyny, dan yang tidak terklasifikasikan. Hal ini sesual dengan hipotesis awal penelitian yang menyebutkan bahwa terdapat perbedaan dalarn perilakı prososial đi antara kelompok masculine, feminine, dan androgyny. Selanjutnya diketahui juga bahwa perbedaan yang signifikan terdapat antara kelompok androgyny dengan kelompok yang tidak terklasifikasikan. Kelompok androgyny memilikí nilai rata-rata skor perilaku prososial yang jauh lebih tinggi dari pad a kelompok tipe 
tidak terklasifikasikan.

Jika dilihat lebih lanjut lagi, kelompok masculine memiliki nilai rata-rata skor perilaku prososial yang relatif rendah. Sementara kelompok feminine memiliki nilai rata-rata skor perilaku prososial yang lebih tinggi dari pada kelompok masculine. Dapat disimpulkan bahwa memang terbukti bahwa hipotesis yang diajukan oleh Tice dan Baumeister (1985) adalah benar. Mereka menyebutkan bahwa maskulinitas menjadi faktor penghambat, sementara femininitas dan androgyny merupakan pemicu perilaku menolong.

Hasil yang sama yang mendukung bukti ini juga didapat dari hasil uj ANOVA terhadap keempat kelompok orientasi peran jenis (masculine, feminine, androgyny, dan tidak terklasifikasikan) terhadap skor perilaku prososial. Secara ringkas dapat diketahui bahwa nilai rata-rata skor perilaku prososial kelompok faminine relatif lebih tinggi dari pada nilai rata-rata skor perilaku prososial kelompok masculine. Nilai rata-rata skor perilaku prososial kelompok feminine sendiri menunjukkan angka 148.32 dengan standard deviasi sebesar 13.167. Nilai ratarata skor perllaku prososial kelompok masculine menunjukkan angka 147.02 dengan standar deviasi sebesar 15.676 .

Pada kesimpulan di atas, disebutkan bahwa secara keseluruhan perilaku prososial subjek wanita jauh lebih tinggi daripada subjek pria. Jika dilihat kembali pada hasil penelitian, disebutkan bahwa berdasarkan studi meta analisis yang dilakukan oleh Eagly dan Crowley (1992) disimpulkan kakau pria lebih menolong daripada wanita, dan wanita lebih cenderung untuk mendapatkan pertolongan. Hal ini sangat bertentangan dengan hasil yang diperoleh dalam penelitian ini. Hasil uji t-test yang membandingkan skor perilaku prososial antara kelompok pria dan wanita menunjukkan kalau kelompok subjek wanita memiliki skor perilaku prososial yang lebih tinggi daripada kelompok sub jek pria.

Beberapa kendala yang memang dihadapi adalah bahwa beberapa penelitian yang telah dianalisis oleh Eagly dan Crowley (1992) memiliki metode yang berbeda, walaupun dikatakan hasilnya konsisten menyatakan pria lebih menolong daripada wanita. Ketika seseorang berhadapan dengan situasi yang secara potensial berbahaya di mana seseorang yang tidak dikenal membutuhkan pertolongan, pria lebih menunjukkan perilaku menolong. Jika situasinya adalah situasi yang bersifat lebih aman dan lebih menuntut dependensi seorang wanita, seperti misalnya terlibat secara sukarela dalam sebuah penelitian, atau secara sukarela bekerja dengan anakanak yang memiliki retardasl mental, temyata wanita lebih menunjukkan perilaku menolong (Myers, 1996). Pria tidak lebih menolong daripada wanita ketika situasi yang dihadapi menuntut empati atau dukungan sosial yang sifatnya kurang aktif (less-active social support) (Basow, 1992).

Kenyataan utama yang dapat diperhatikan kembali adalah bahwa penelitian yang dilakukan oleh Eagly dan Crowley (1992) dilakukan terhadap siswasiswa di Amerika Serikat. Penelitian pada mahasiswa di Universitas Sumatera Utara sendiri belum pemah dilakukan penelitian secara general untuk mencari tahu apakah kelompok pria menunjukkan kecenderungan untuk menolong yang lebih tinggi daripada wanita. Berdasarkan penelitlan yang dilakukan pad a 100 orang subjek mahasiswa pria dan 100 orang mahasiswa wanita kali ini menunjukkan hasil yang jauh berbeda. Pada penelitian tersebut wanita dilaporkan menunjukkan perilaku prososial yang lebih tinggl daripada pria. Selanjutnya perlu diakukan pembahasan leblh luas terhadap definisi operasional penelitlan untuk perilaku prososial. Beberapa peneliti dalam Psikologi Sosial lebih berpendapal bahwa penelitian terhadap tingkah laku sosial lebih akurat jika dilakukan dengan pengukuran observasi terhadap tingkah laku secara langsung. Tingkah laku prososial harus diobservasi secara langsung dari subjek penelitian dalam satting alaminya untuk mendapatkan hasil yang lebih akurat (Azwar, 2000). 


\section{Penutup}

Berdasarkan hasil yang diperoleh dari penelitian ini, maka ada beberapa saran yang penulis berikan untuk lebih menyempumakan hasil maupun penelitian lanjutan, terutama yang berkaitan dengan studi mengenai orientasi peran jenis.

Hal-hal yang penulis sarankan antara lain dengan melakukan penelitian yang serupa, totapi dengan menggunakan metode pengukuran yang berbeda seperti obsevasi dan wawancara, dengan tujuan untuk mendapatkan gambaran mengenai perilaku prososial dalam setting yang alami; menggunakan sampel lain (nonmahasiswa); serta lebih jauh meneliti perilaku prososial ditinjau dari faktor-faktor lain yang mempengaruhinya.

\section{Daftar Pustaka}

Amato, P. R 1990. Personality and Social Network Involvement as Predictors of Helping Behavior in Everyday Life. Social Psychology Quarterly, vol. 53, no. 1, pages 31-43.

Andreoni, J., \& Vesterlund, L. 2001. Which is The Fair Sex? Gender Differences in Altruism. The Quarterly Joumal $O$ Economics, vol. 116, issue 1, pages 293312.

Azwar, S., MA 2000. Penyusunan Skala Psikologi. Yogyakarta: Pustaka Pelajar.

2000. Sikap Manusia. 'Teori dan 'Pengukurannya. Edisi Kedua. Yogyakarta: Pustaka Pelajar.

Baron, R. A., \& Byrne, D. 2000. Social Psychofogy $\left(\theta^{\text {th }}\right.$ ed).Allyn \& Bacon.

Ba sow, S. A. 1992. Gender: Stereoty,oes And Roles ( $3^{\text {te }}$ ed). California : Brooks/Cole Publishing Company.
Beere, C. A 1990. Gender Roles: a handbook of test and measures. New York: GreenWood Press

Brigham, J. C.. 1986. Social Psychology. Boston : Liltile, Brown \& Company.

Dagun, S. V, 1992. Masculine dan Feminine (terjemahan), Jakarta: Rineka Cipta.

Deaux, K., Dane, F. C., \& Wrightsman, L S. 1993. Social Psychology in the $90 / \mathrm{s} 16^{\mathrm{m}}$ ed). California : Brooks/Cole Publishing Company.

Eagly, A. H., Beall, A E., Stemberg, R J., 2004. The Psycliology of Gender (2 ${ }^{\text {nd }}$ edition). New York The Guilford Press.

Feldman, R. S. 1992. Elements of Psychology (International Edition). New York: McGraw-Hill, Inc

1996. Understanding Psychology (4 ed). New York : McGraw-Hili, Inc

1995. Social Psychology. New Jersey: Prentice Hall, Inc

Hadi, S. 2000. Metodologi Research (Gitid 1), Yogyakarta :ANDI

(j) ilin $\overline{7}$. $\overrightarrow{\mathrm{Y}}$. pgdkata :ANDI

2000. Metodologi Research 2000. Metodologl Research

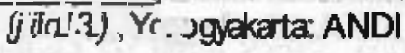

Hall, C. S., Lindzey, G., Loehlin, J. C., Manosevits, M. 1985. Introduction To Theories of Personality. New York: John Wiley \& Sons.

Hollander, E P 1981. Principles And Methods of Social Psychology $\left(4^{\mathrm{m}} \mathrm{ed}\right)$. New York: Oxford University Press

Langdridge, D. 2004. Introduction to: Research Methods and Data Analysis 
in Psychology. London : Pearson Education Limited.

Lindzey, G. 1954. Handbook of Social Psychology. Addison-Wesley Publishing Company, Inc

Myers, D. G.1996. ExploringPsychology $\left(3^{\text {rd }}\right.$ ad). New York: Worth Publishers, Inc

$\left(5^{\text {th }}\right.$ ed) New York: McGraw-Hill

Nauly, M. 2003. Fear Of Success Wanita Bekerja, Studi Banding Perempuan Batak, Minangkabau Dan Jawa. Yogyakarta: Arti

2003. Konfik Gender \& Sekslsme, Studi Banding Laki-Laki Batak, Minangkabau Dan Jawa. Yogyakarta:Arti

Oskamp, S. 1984. Applied Social Psychology. New Jersey : PrenticeHall, Inc.

Papalia, D. E., Skems, H. L., Feldman, R D., Camp, C. J. 2002. Adult Development and Aging ( $2^{\text {nd }}$ ed) McGraw-Hill, inc.

Papalia, D. E. \& S. W. Olds. 1995. Human Development. New York: McGraw-Hill.

Saks, M. J. \& Krupat, E 1988. Social Psychology And its Applications. New York: Happer \& Row, Publishers.

Santoso, S. 2001. SPSS Versi 10. Mengolah Data Statistik Secara Profesional. Jakarta: PT. Elex Media Komputindo.
Santrock, J. W, 1998. Adolescence ( $7^{\text {th }}$ @d), McGraw-Hill, Inc.

Schultz, D., \& Schultz, S. E 1994. Theories of Personality $\left(5^{\text {th }}\right.$ ed). California: Brooks/Cole Publishing Company.

Segall, M H., Dasen, P. R., Berry, J. W. \& Poortinga, Y. H. 1990. Human Behavior in Global Perspective: An Introduction To Cross-Cultural Psychology. Great Britain : Pergamon Press.

Simanjuntak, Y. E. 2003. Perbedaan Kepuasan Kerja Pada Dokter Perempuan Dengan Tipe Orientasi Peran Gender Masculine, Feminine, Dan Androgini. Skripsi. Medan: Program Studi Psikologi, Fakultas Kedokteran, Universitas Sumatera Utara.

Suryabrata, S. 2002. Pengembangan Alat Ukur Psikologis. Yogyakarta : Penerbit Andi.

Taylor, S. E., Peplau, L.A., \& Sears, D. O. 2000. Social Psychology (10" ed). New Jersey: Prentice-Hall, Inc.

Bystander Intervention Processes: Variables That Inhibit and Facilitate Helping Behavior. (2002, Agustus), University of Northern lowa (On-line) http://fp.uni.edu/yates/Research $\% 20$ Methods/bib\%201.pdf 